\title{
Empirical Testing of the Response of Czech Stock Market to Downgrades of Greek Credit Rating in the Light of the Efficient Market Hypothesis
}

\author{
Petr Sed'a1, Juan Antonio Jimber del Río² , María de los Baños García- \\ Moreno García ${ }^{3}$ \\ ${ }^{1}$ VSB-Technical University of Ostrava \\ Faculty of Economics, Department of Mathematical Methods in Economics \\ Sokolská třída 33, 70121 Ostrava 1, Czech Republic \\ E-mail: petr.seda@vsb.cz \\ 2 University of Córdoba \\ Faculty of Law and Business and Economic Sciences, Department of Economics, Sociology \\ and Agricultural Policy, Area of Financial Economy and Accounting \\ Puerta Nueva S/N, 14071-Córdoba, Spain \\ E-mail: jjimber@uco.es \\ ${ }^{3}$ University of Córdoba \\ Faculty of Law and Business and Economic Sciences, Department of Statistics, \\ Econometrics, Operational Research and Applied Economics \\ Puerta Nueva S/N, 14071-Córdoba, Spain \\ E-mail: d52gagam@uco.es
}

\begin{abstract}
Empirical testing of the linkages between macroeconomic news and asset price movements in terms of response to released macroeconomic information have been a subject of many investigations using different testing methods. The objective of this paper is to study the impact of announcements of Greek credit rating downgrades on the prices of the most liquid assets quoted in the Czech stock market. This issue is tightly related to semi-strong form of the efficient market hypothesis, which is one of possible analytical approaches when analyzing behaviour of assets in financial markets. The reaction of the Czech stock market is assessed in relation to seven announcements of Moody's rating agency regarding changes of credit rating of Greek government bonds in the period 20092012. For the purpose of this paper, the event study methodology is applied. The basic idea of this statistical method is to determine values of abnormal returns, which can be defined as a difference between actual and equilibrium returns. In order to calculate equilibrium returns, the Capital Asset Pricing Model (CAPM) is used. The differences between actual and equilibrium returns are then verified with a help of selected nonparametric statistical tests. Namely, the exact sign test and the Wilcoxon signed-rank test are utilized. Based on results of nonparametric statistical tests, the null hypothesis of information efficiency of the Czech stock market is conclusively rejected.
\end{abstract}

Keywords: CAPM, Czech stock market, event study, semi-strong form of efficiency, nonparametric tests

JEL codes: C12, G14, G18 


\section{Introduction}

The knowledge of possible impact of macroeconomic news on stock prices is important when assessing stock market efficiency. The impact of macroeconomic information on equity prices for assessment of stock market efficiency and possible forecasting of stock market reactions have received a considerable attention in academic literature (Gurgul and Wójtowicz, 2015). The issue of testing the response of stock markets to announcement of macroeconomic news is very topical especially if we consider the recent global financial crisis. The global financial crisis and subsequent debt crisis significantly hit stock markets worldwide. The Czech Republic, an export-oriented economy with substantial reliance on foreign capital, was not an exception. The fund withdrawal led by foreign investors in the Czech stock market exacerbated volatility in stock market and decline of the whole market by more than $60 \%$ (Sed'a, 2012).

Greece is one of the countries that were affected by the global financial crisis and the subsequent debt crisis fatally (Švihlíková, 2010). This fact led to repeated downgrades of Greek government bonds rating. Since mutual relations among stock markets grew during the global financial crisis (Sed'a and Jimber del Río, 2014), crucial events in the Greek financial market could lead to a significant reaction also in the Czech stock market. An effect of increasing linkages between markets around the world was confirmed for instance by Nikkinen et al. (2006), Kim and Nguyen (2008) or Albuquerque and Vega (2009). Macroeconomic announcements that concern one economy can simply influence not only the domestic stock market but also their foreign counterparts significantly.

The objective of this paper consists in empirical testing of the impact of announcements of Greek credit rating downgrades on the prices of the most liquid assets quoted in the Czech stock market. A response of the Czech stock market will be measured. This includes its strength, direction and duration to changes of credit rating of Greek government bonds as published by Moody's agency in the period 2009-2012. For the purpose of this paper, the event study methodology will be utilized.

The added value of this paper consists in the following aspects. Firstly, this paper contributes to the discussion about information efficiency of the Czech stock market, which is still considered an emerging market. Secondly, empirical studies focusing on testing the response of stock markets usually work with macroeconomic news that are announced on regular basis (monthly, quarterly or yearly). This paper works with irregular news. Thirdly, statistical evaluation of results is performed merely via utilization of the data in the form of returns of stock indexes. In this paper, we also utilized log returns of particular shares that form the base of the main index $P X$.

The rest of the paper is organized as follows. In chapter 2, the theoretical basis of the event study method will be discussed thoroughly. In addition, the methods of calculating the actual, equilibrium and abnormal returns will be defined. Finally, 
selected non-parametric tests, which are usually used for statistical evaluation of abnormal returns, will be described. In section 3, we present the data used in this paper and give a brief description of the Greek crisis and related development of Greek government bonds rating. The application part of this paper is presented in section 4. It mainly contains empirical testing of the Czech stock market reaction to announcements of Greek credit rating downgrades and consequent statistical evaluation of results. The final section concludes this paper and opens possible extensions of the topic investigated.

\section{Theoretical Background of Efficient Market Hypothesis}

The behavior of stock prices has been a subject of many recent investigations. Most theories claim that prices in stock markets are efficient and therefore cannot be forecasted. However, practitioners have never believed it, and naturally tried to maximize profit using sophisticated forecasting methods. The efficient market hypothesis is almost certainly the right place to start when thinking about asset price formation. The basic idea of the efficient market hypothesis is based on the determination of equity prices by interaction of interested rational market agents. Information efficiency depends on how market prices reflect all relevant information (Fama, 1970).

The efficient market hypothesis says that at any given time, security prices fully reflect all available information (Sed'a and Jimber del Río, 2016). Market efficiency is defined within a hierarchy of three nested information sets. Considering this hierarchy of information, we can define efficiency with respect to increasing amounts of information (Fama, 1970):

- Weak form of efficiency - means that no investor can earn excess returns by developing trading rules based on historical prices or return information.

- Semi-strong form of efficiency - denotes that it is impossible to earn above average profit from trading based on any publicly available information.

- Strong form of efficiency - implicates that market agents cannot earn above average returns when using any information, whether public or private.

Figure 1 describes the below mentioned sets of information:
A - All available information,
B - Publicly available information,
C - Historical price information.

It is obvious, that the following implications hold:

$C \subset B \subset A$ 
Figure 1 Information sets

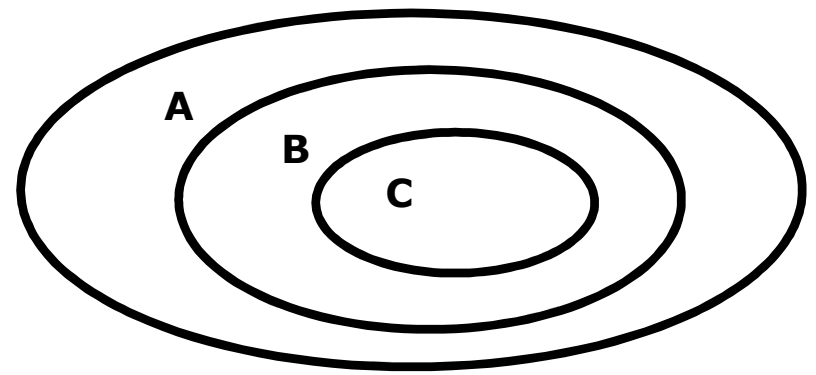

Source: Authors' elaboration

Equation (1) implies that testing the semi-strong form of efficiency is usually focused on a measurement of a speed with which new publicly available information is absorbed in stock prices. Public announcements of important macroeconomic data about inflation, production, profit and other economic variables cause considerable attention in both financial literature and practically oriented analyses. Practitioners and academicians are interested in the knowledge which macroeconomic information are reflected in prices of financial instruments and how.

\section{Literature Review}

In the economic literature, there is a lot of evidence for the effect of macroeconomic news on the stock market performance. The authors predominantly examined just developed stock markets. Boyd et al. (2005) investigated the impact of U.S. unemployment rate on the S\&P stock index. Albuquerque and Vega (2009) confirmed a delayed reaction of the Portuguese stock market to the U.S. news release. Dimpfl (2011) showed that investors on the Frankfurt Stock Exchange reacted immediately after news announcement. Moreover, significant reactions were observed in the first ten minutes. Singh et. al (2013) utilized data from developed stock markets and confirmed that U.S. macroeconomic announcements influenced volatility rather than stock returns.

However, Central and Eastern European (CEE) stock markets with respect to the semi-strong form of efficiency have been investigated only rarely. Investigators usually examined just the weak form of efficiency of these markets. In addition, research studies are not updated (Tran, 2007). Kiete and Uloza (2005) investigated the semi-strong form of efficiency in CEE using the event study methodology. They only examined the Lithuanian and Latvian stock markets and concluded that the null hypothesis of efficiency cannot be rejected in the case of Lithuanian stock market in the period 2001-2004. Nikkinen et al. (2006) investigated the impact of U.S. macroeconomic news releases on 35 different stock markets including CEE stock markets. The reaction of CEE stock markets including the Czech stock market to the announcement of U.S. indicators was insignificant. Contrary to that, Hanousek et al. (2009) investigated the reaction of Central European stock markets to the announcement of news from the USA and eurozone. More precisely, they 
examined how stock prices in the Czech Republic, Hungary and Poland responded to macroeconomic news coming from the USA and eurozone. They found that the strongest reaction to data announcements from the USA was observed in the Czech stock market. Nevertheless, Buttner et al. (2012) found that the EU macroeconomic news outbalanced the impact of U.S. news in the Czech equity market. Moreover, Büttner and Hayo (2012) investigated the impact of political and fiscal news and found that those shocks significantly affected long-term bond yields and, to a lesser extent, other financial variables in the Czech Republic, Hungary and Poland. Égerd and Kočenda (2014) examined the impact of macro news and central bank communication on the emerging European forex markets. They showed that GDP announcements had a significant impact on the CZK/EUR rate during the global financial crisis period. Hanousek and Kočenda (2001) analyzed macroeconomic news and spillovers in the Czech, Hungarian and Polish stock markets and proved that interactions in those markets are strongly determined by the U.S. and EU stock markets as well as the macroeconomic news originating thereby. Gurgul and Wójtowicz (2014) examined reactions of the Polish stock market to U.S. announcements. Hence, this paper contributes to the discussion on the efficiency of newly emerged stock markets in transition economies.

\section{Methodology}

In this section, a brief description of experimental methods used in this paper will be given. For the purpose of this paper, the event study method will be utilized. In addition to this, the methods of calculating the actual, equilibrium and abnormal returns will be explained.

\subsection{Procedure of Event Study}

The most commonly used approach to assess the potential impact of macroeconomic news announcements on stock prices is based on regression with dummy variables or quantile regression (Harju and Hussain, 2011). However, this method has some serious imperfections because of intraday volatility patterns and overnight returns (Gurgul and Wójtowicz, 2014). In order to avoid these imperfections, we utilized the event study method. This method has been also widely applied when investigating the impact of news announcements on daily data (Corrado and Troug, 2008). Since the event methodology can be used to elicit the effects of any type of macroeconomic event on the direction and magnitude of stock price changes, this approach is very versatile. In general, the event study is a statistical method to assess the impact of economic event on the value of financial assets. This approach is thus commonly used in various research areas in economics, such as accounting (Cready and Gurun, 2010) and finance (Trung, 2011). Some examples include announcements of macroeconomic variables or corporate events like earnings announcements or mergers and acquisitions. However, the event study method has some reservations in relation to the assessment of economic policy (Beigi and Budzinski, 2013). Another imperfection is related to the robustness of this approach to outliers (Sorokina et al., 2013). 
History of the event study is relatively long. This approach was used for the first time by Dolley (1933), followed later for instance by Ashley (1962). Later on, this methodology was significantly developed by Fama (1969). In later years, there have been defined many modifications that should eliminate complications resulting from violations of statistical assumptions (MacKinley, 1997). When testing the reaction to announcement of macroeconomic news, it is possible to describe the event study method in the following five steps:

- definition of the event and timeline,

- calculation of actual returns,

- determination of equilibrium returns,

- calculation of abnormal returns,

- verification of statistical significance and economic interpretation of the results.

The structure of an event should be defined prior to testing a response of a stock market to new information announcement. The timing sequence is illustrated with a timeline in Figure 2. It consists of three basic windows or periods that do not overlap. These periods are as follows:

- estimation window,

- event window, and

- post event window.

Figure 2 The general timeline for an event study

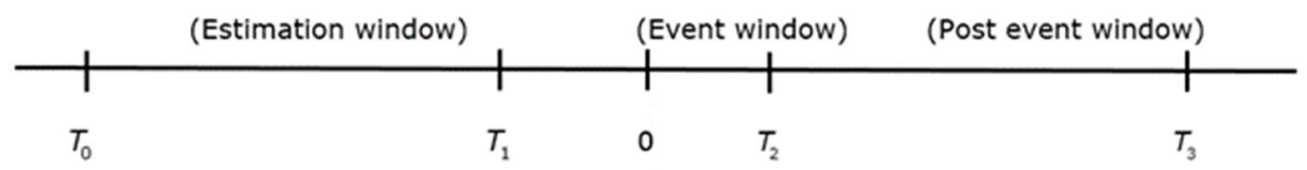

Source: MacKinley (1997)

The estimation window is a period preceding the event window. The estimation window represents an interval with the length of $L_{1}=T_{1}-T_{0}$. The estimation window is a period that is used for calculating the actual returns and coefficients of financial models. It is recommended to be 100-250 days long when using daily data. The event window represents a period when new information was published. Even if the event is represented by an announcement on a given date, it is recommended to set the event window length to be longer than just one day (MacKinley, 1997). This condition facilitates the use of abnormal returns around the event day in the analysis. The event window is defined as an interval with a length of $L_{2}=T_{2}-T_{1}$. Finally, the post event window is defined as an interval with a length of $L_{3}=T_{3}-T_{2}$. After identification of an event and definition of the term structure, it is necessary to establish criteria for selection of companies used for the purpose of the event study. It is also important to determine whether market response to the announcement of new events will be tested via usage of daily data, 
which are characterized by higher volatility over time compared to data of lower frequency.

\subsection{Calculation of Equilibrium and Abnormal Returns}

The basic idea of the event study method is to compare normal or actual returns with their equilibrium returns during the event window period. The differences between actual and equilibrium returns represent abnormal returns. Normal returns have to be calculated not only for the event window but also for the estimation window period. If the rate of returns from holding the shares is to move in a reasonable interval that is not too high, we can replace the percentage rate of return yield by a logarithmic rate of return. Withing this paper, we defined normal returns in the following way:

$R_{t}=\ln \frac{P_{t}}{P_{t-1}}=\ln \left(P_{t}\right)-\ln \left(P_{t-1}\right)$

where $R_{t}$ is the logarithmic return, $P_{t}$ and $P_{t-1}$ are the prices of assets at time $t$ and $t-1$, respectively.

Equilibrium returns can be defined as returns that would be achieved by trading agents if new information had not been published. Equilibrium returns are based on values of coefficients of financial models used for the purpose of the event study. These coefficients are necessary for calculation of equilibrium returns for the event window period. Equilibrium or expected returns represent a benchmark actual returns are compared with. Economic models allow precise calculation of equilibrium returns thanks to the determination of economic constraints (Campbell et al., 1997). The most common economic model that is used to determine equilibrium returns in financial modeling is the Capital Asset Pricing Model (CAPM). However, the market model can be applied as well.

The CAPM was built on diversification and modern portfolio theory. Sharpe (1964) and Lintner (1965) introduced this model independently. If all assumptions of the CAPM were met, it would be possible to consider a stock market to be efficient in its strong form. Semi-strong and weak forms of market efficiency are characterized by omitting or changing some of these assumptions (Kohout, 1995).

According to CAPM model, the expected return can be calculated as follows:

$E\left(R_{i \tau}\right)=r_{f}+\hat{\beta}_{i}\left(E\left(R_{M \tau}\right)-r_{f}\right)$

where $E\left(R_{i \tau}\right)$ is the expected return of $i$-th share, $r_{f}$ is the risk-free rate, $\hat{\beta}_{i}$ represents the parameter of share sensitivity, and $E\left(R_{M_{\tau}}\right)$ is the expected return of market portfolio. When testing the reaction of the Czech stock market, a necessary condition is to measure values of abnormal returns. Let $A R_{i \tau}$ be a sample of $L_{2}$ abnormal returns for $i$-th share in the event window. The sample abnormal return is given by: 
$A R_{i \tau}=R_{i \tau}-E\left(R_{i \tau}\right)$

where $R_{i \tau}$ is the normal return of $i$-th share. In order to evaluate the reaction of the Czech stock market and assess the absorption rate of newly published information, it is necessary to sum up the calculated values of abnormal returns within the event window period. The abnormal returns thus must be aggregated in order to draw overall inferences for the event of interest. The aggregation should have two dimensions - through time and securities. Let's define $C A R_{i}\left(\tau_{1}, \tau_{2}\right)$ as the sample cumulative abnormal return $(C A R)$ from $\tau_{1}$ to $\tau_{2}$ where $T_{1}<\tau_{1} \leq \tau_{2} \leq T_{2}$. The CAR from $\tau_{1}$ to $\tau_{2}$ is the sum of abnormal returns:

$\operatorname{CAR}_{i}\left(\tau_{1}, \tau_{2}\right)=\sum_{\tau=\tau_{1}}^{\tau_{2}} A R_{i \tau}$

The abnormal returns must be aggregated for the event window. The absence of any overlap and distributional assumptions imply that abnormal returns and cumulative abnormal returns will be independent across securities. The abnormal returns of individual shares can be aggregated using $A R_{i \tau}$ from equation (4) for each event period $\tau=T_{1}+1, \ldots, T_{2}$. Given $N$ events, the sample average aggregated abnormal returns for period $\tau$ is given by:

$\overline{A R_{i \tau}}=\frac{1}{N} \sum_{i=1}^{N} A R_{i \tau}$

where $N$ is a number of events included. The average cumulative abnormal returns can then be aggregated over the event window using the same approach that was used to calculate the cumulative abnormal return for $i$-th security. It can be calculated for any interval within the event window as follows:

$\overline{\operatorname{CAR}_{i}}\left(\tau_{1}, \tau_{2}\right)=\sum_{\tau=\tau_{1}}^{\tau_{2}} \overline{A R_{i \tau}}$

Testing the reaction of the Czech stock market to news release will be carried out just on the basis of $\overline{A R_{i \tau}}$ and $\overline{C A R_{i}}\left(\tau_{1}, \tau_{2}\right)$.

\subsection{Nonparametric Tests}

Reaction of the Czech stock market to news release regarding changes of Greek credit rating must also be evaluated statistically. Otherwise, one cannot make any conclusion in relation to the efficient market hypothesis. If a stock market is efficient, an announcement of new information should be reflected in stock prices immediately. The basic idea of semi-strong form of efficiency can be expressed as follows: if a stock market is efficient, there should not be a statistically significant difference between actual and equilibrium returns. In other words, abnormal returns should not significantly differ from zero. 
If the assumption of normality of abnormal returns is violated, selected nonparametric statistical tests should be utilized. The most suitable and commonly used nonparametric tests are the sign test and the Wilcoxon signed-rank test (Hendl, 2009). When testing the reaction of a stock market in the light of efficiency, the null and alternative hypothesis can be therefore defined as follows:

$$
\begin{aligned}
& H_{0}: \overline{A R_{i \tau}}=0, \\
& H_{1}: \overline{A R_{i \tau}} \neq 0 .
\end{aligned}
$$

\section{Sign Test}

The sign test, which is also known as the median test, is based on the assessment of directions of deviations from expected value of the median $\tilde{\mu}_{0}$. Under the null hypothesis, the number of positive and negative deviations from median $\tilde{\mu}_{0}$ should be approximately the same.

Testing the null hypothesis can be performed using the exact test or the asymptotically valid test. When applying the exact test, the binomial distribution is used for the $Z_{+}$value. $Z_{+}$is the number of $d_{i}=x_{i}-\tilde{\mu}_{0}$ with positive signs (Hendl, 2009). When running the asymptotically valid test, which is based on approximation using the normal distribution, it is necessary to calculate test statistics $z$ according to the following formula:

$Z=\frac{2 Z_{+}-n}{\sqrt{n}}$

If the test statistic $z$ lies in the interval $\left(-z_{\alpha / 2},+Z_{\alpha / 2}\right)$, where $\pm Z_{\alpha / 2}$ represent the standardized value of the normal distribution, we accept the null hypothesis $H_{0}$ and reject the alternative hypothesis $H_{1}$ (Hendl, 2009). The asymptotically valid test can be used when the sample size is greater than the value of 25 .

\section{Wilcoxon Signed-rank Test}

The Wilcoxon signed-rank test for one sample is more powerful than the sign test. This test is based on comparison of absolute values of positive and negative deviations from estimated values of the median $\tilde{\mu}_{0}$, which are sorted by size. Under the null hypothesis, the total sums of $T_{-}$and $T_{+}$should be approximately the same. In the case of a larger sample size, an approximation by normal distribution is used. When assuming the null hypothesis, the test statistic $z$ is then calculated by standardizing the variable $T_{+}$with a help of theoretical mean $E(T)$ and standard deviation $\sigma_{T}$. The test statistic $z$ can be given:

$Z=\frac{T_{+}-E(T)}{\sigma_{T}}$ 
Approximation by normal distribution is recommended to be used if the sample size is greater than value of 25 only. If the test statistic $z$ lies within the interval $\left(-Z_{\alpha / 2},+Z_{\alpha / 2}\right)$, where $\pm Z_{\alpha / 2}$ represent the standardized value of the normal distribution, the hypothesis $H_{0}$ cannot be rejected (Hendl, 2009).

\section{Data Sample Selection}

The reaction of the Czech stock market will be investigated using data from the Czech stock market in the period 2009-2012. We will use log-returns calculated according to equation (2) of just 12 shares, which were included in the PX index base during the complete testing period.

\subsection{Changes in Greek Credit Rating}

Changes of credit rating of Greek government bonds as published by Moody's international rating company in the period 2009-2012 have become a key motivation for this paper as Greece is one of the countries that were surely significantly affected by the global financial crisis and subsequent debt crisis. GDP per capita in market prices decreased from 21,400 to 17,300 EUR (Mavridis, 2018). This period is also characterized by higher volatility of stock markets (Sed'a, 2012). Critical situation of Greek economy was mainly caused by huge public expenditures, which are related to the high level of employment in the public sector and premium wages as well as high pension payments (Švihlíková, 2010). Changes of Greek credit rating as published by Fitch and S\&P agencies are not examined in the paper because these companies utilize different rating methodologies.

The poor state of Greek public finances was a major reason for credit rating downgrade from grade $A 1$ to $A 2$ on 22 December 2009. Rating downgrade resulted in a fall in prices of Greek securities and decline of euro currency against US dollar. The reason for credit rating downgrade from $\mathrm{A} 3$ to $\mathrm{Ba} 1$ was especially a high rate of economic risks associated with the implementation of the rescue program as proposed to Greece by the Eurozone countries together with the International Monetary Fund. Further decline in credit rating happened on 14 June 2010 when Moody's downgraded Greek credit ratings to a speculative level. Next, Greek credit rating was downgraded by Moody's on 7 March 2011 by three steps deeper from Ba1 to B1 level into the highest risk zone called "junk bonds". In that case, the reason of credit-rating downgrade was a lack of confidence in reforms which should help to correct deficit financing and lack of government revenue. Moody's downgraded the credit rating of Greece's commitments by next three steps to Caa1 level on 1 June 2011 because of increasing risk of government's inability to stabilize its debt without restructuring. Greek rating downgraded again as a result of extraordinary summit of euro members on 27 July 2011. Credit rating shrank to the lowest possible grade C on 3 February 2012 as a result of private investors' decision regarding the exchange of bonds. As a consequence, creditors wrote off more than $50 \%$ of the nominal value of Greek bonds. The largest creditors of Greek government bonds are especially domestic banks, e.g. National Bank of Greece, 
Eurobank, and Alpha. The most important foreign creditors are especially French and German financial institutions. Development of credit rating of Greek government bonds is given in Table 1.

Table 1 Changes in credit rating of Greek government bonds

\begin{tabular}{cc}
\hline Date & Rating \\
\hline \hline 22. 12. 2009 & $\mathrm{~A} 2$ \\
\hline 27. 4. 2010 & $\mathrm{~A} 3$ \\
\hline 14.6.2010 & $\mathrm{Ba} 1$ \\
\hline 7. 3.2011 & $\mathrm{B} 1$ \\
\hline 1.6.2011 & $\mathrm{Caa} 11$ \\
\hline 25.7.2011 & $\mathrm{Ca}$ \\
\hline 3.2.2012 & $\mathrm{C}$ \\
\hline
\end{tabular}

Source: wwW.moodys.com

\subsection{Czech Stock Market}

As has been already mentioned in Introduction, the reaction of the Czech stock market on news release is investigated using data sample in the period 2009-2012. Prague Stock Exchange (PSE) is the largest and oldest organizer of stock market in the Czech Republic. After a fifty-year break caused by World War II and the Communist regime, PSE was reopened in 1993. Trading on PSE is conducted via licensed securities traders who are also the PSE members. These are primarily the major banks and brokerages. If a common investor decides to invest in the Exchange, he/she needs to contact one of the trading members. The PX index is the main price index of the PSE and it is calculated in a real time. It is a free float weighted price index made up of the most liquid assets. This index does not take into account the dividend yields. Updating the base of the index is to maintain the quality index performed each quarter. The PX contains the most liquid titles with weights changing according to the market capitalization. At the present time, the actual number of the basic issues is variable. However, in accordance with the Principles of Updating the Base of the Index PX, which were approved in December 2001, the base cannot consist of more than 50 issues (Březinová, 2013). On 29 October 2007 it reached its top with 1936 points and ended the year with 1815 points. As a result of the global financial crisis, the PX index reached the value of 700 points on 27 October 2008, losing more than $50 \%$ of its value in two months. The bottom was reached on 18 February 2009 with 629 points (Sed'a, 2012). The reaction of the Czech stock market on news announcement is tested using shares, which are included in the PX index base. In addition, we use just the shares that were included in the PX index base during investigated period 2009-2012. The "modified" base of the PX index is shown in Table 2. 
Table 2 Modified PX index base

\begin{tabular}{cccc}
\hline & $\begin{array}{c}\text { Opening } \\
\text { of trading }\end{array}$ & & $\begin{array}{c}\text { Opening } \\
\text { of trading }\end{array}$ \\
\hline \hline AAA & 22.6 .1993 & ORCO & 13.7 .1993 \\
\hline CETV & 5.2 .2008 & $\begin{array}{c}\text { Pegas } \\
\text { Nonvowens }\end{array}$ & 18.12 .2006 \\
\hline ČEZ & 1.10 .2002 & Philip Morris & 1.2 .2005 \\
\hline Erste group & 22.6 .1993 & Telefonica & 27.6 .2005 \\
\hline Komerční banka & 1.3 .1995 & Unipetrol & 22.10 .2012 \\
\hline NWR & 28.8 .1997 & VIG & 22.10 .2010 \\
\hline
\end{tabular}

Source: Summarized by authors based on PSE website

\section{Empirical Results}

When testing the reaction of the Czech stock market in the light of the semi-strong form of efficiency using the event study method, the most important and significant periods are the estimation window and the event window. In this paper, the length of the estimation window is one year. The event window is a period within which the speed of absorption of new information is tested. For the purpose of this paper, the event window consists of 15 trading days before the publication of new information and 15 trading days after the publication of new information. "Zero day" is set on the date of announcement of new information. To sum up, the event window consists of 31 trading days. The timeline for our event study is graphically presented in Figure 3.

Figure 3 Timeline for event study

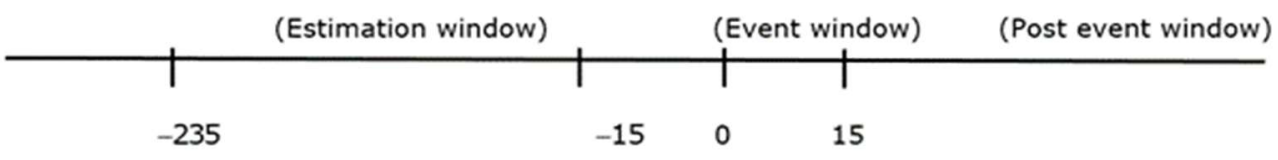

Source: Authors' elaboration

\subsection{Calculating the Abnormal Returns}

The response of the Czech stock market to announcements of changes of Greek credit rating will be tested through the average aggregated abnormal returns and average cumulative abnormal returns, which are calculated according to equations (6) and (7). In order to estimate equilibrium returns according to CAPM model, it is necessary to set risk-free rate $r_{f}$. The values of $r_{f}$ are determined as average gross yields of Czech government bonds (Březinová, 2013). In this paper, the riskfree rates for the period 2009-2012 are determined by gross monthly returns of 3year government bonds as shown in Table 3. 
Table 3 Value of risk-free rate (in \%)

\begin{tabular}{lllll}
\hline & $\mathbf{2 0 0 9}$ & $\mathbf{2 0 1 0}$ & $\mathbf{2 0 1 1}$ & $\mathbf{2 0 1 2}$ \\
\hline Yields of Czech government bonds & 2.945 & 1.762 & 1.926 & 0.926 \\
\hline
\end{tabular}

Source: Březinová (2013)

Abnormal returns are calculated as differences between normal (actual) and equilibrium returns. Equilibrium returns have been calculated using the CAPM model according to equation (3). In order to assess the response of the Czech equity market to the changes of Greek credit rating, it was necessary to determine average aggregate abnormal returns and cumulative average abnormal returns for the event window. By averaging the abnormal returns for each day of the event window, we obtained aggregated abnormal returns. Next, we calculated cumulative abnormal returns. Since credit rating of Greek government bonds changed seven times in the period 2009-2012, it was also necessary to calculate average values of aggregated returns (Březinová, 2013).

Table 4 Values of average aggregated abnormal and cumulative abnormal returns of the Czech equity market according to CAPM in \%

\begin{tabular}{ccc}
\hline Days & $\overline{A R_{i \tau}}($ CAPM $)$ & $\overline{C A R_{i}}($ CAPM $)$ \\
\hline \hline-15 & -1.140 & -1.140 \\
\hline-14 & -1.289 & -2.429 \\
\hline-13 & -0.907 & -3.336 \\
\hline-12 & -1.124 & -4.459 \\
\hline-11 & -1.191 & -5.651 \\
\hline-10 & -1.061 & -6.712 \\
\hline-9 & -1.712 & -8.424 \\
\hline-8 & -1.240 & -9.664 \\
\hline-7 & -1.321 & -10.985 \\
\hline-6 & -1.560 & -12.545 \\
\hline-5 & -1.674 & -14.219 \\
\hline-4 & -1.115 & -15.334 \\
\hline-3 & -0.985 & -16.318 \\
\hline-2 & -0.880 & -17.198 \\
\hline-1 & -1.109 & -18.307 \\
\hline 0 & -1.248 & -19.555 \\
\hline 1 & -1.366 & -20.921 \\
\hline 2 & -1.190 & -22.111 \\
\hline 3 & -1.013 & -23.124 \\
\hline 4 & -1.160 & -24.284 \\
\hline 5 & -0.907 & -25.193 \\
\hline 6 & -1.488 & -26.679 \\
\hline 7 & -1.218 & -27.898 \\
\hline 8 & -1.382 & -29.281 \\
\hline & &
\end{tabular}




\begin{tabular}{ccc}
\hline Days & $\overline{A R_{i \tau}}($ CAPM $)$ & $\overline{C A R_{i}}($ CAPM $)$ \\
\hline \hline 9 & -1.682 & -30.963 \\
\hline 10 & -1.962 & -32.925 \\
\hline 11 & -2.166 & -35.092 \\
\hline 12 & -0.987 & -36.078 \\
\hline 13 & -1.502 & -37.581 \\
\hline 14 & -0.073 & -37.654 \\
\hline 15 & -0.858 & -38.512 \\
\hline
\end{tabular}

Source: Authors' elaboration

The values presented in Table 4 show that the amount of aggregated abnormal returns according to the CAPM reached only negative values throughout the event window. It means that the actual returns reached lower values than returns estimated according to CAPM model on average. Regarding publication of information on "zero day", it can be concluded that no significant deviations from reference values have been observed. Thus, the publication of new information did not result in a jump drop. The values of average aggregated abnormal and cumulative abnormal returns of the Czech stock market for the period of fifteen days before and after announcement of seven credit rating changes are graphically shown in Figure 3.

Figure 3 Average aggregated abnormal returns and cumulative average abnormal returns of the Czech stock market
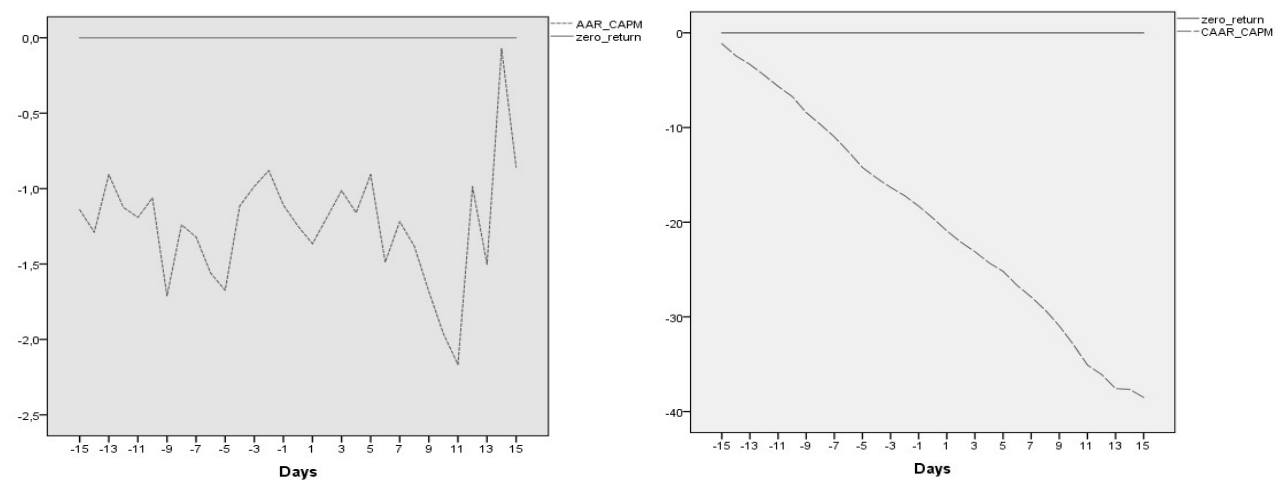

Source: Authors' elaboration

Figure 3 also shows the values of cumulative average abnormal returns based on equation (6). Market response to announcement of new information is not evident. The most striking reaction can be observed between the $7^{\text {th }}$ and the $11^{\text {th }}$ days after the news release. Average aggregated abnormal returns achieved almost zero value just 14 days after news announcement. The cumulative abnormal losses on the day of announcement achieved the value of $-19.56 \%$. The abnormal returns calculated according to CAPM model started to decrease already fifteen days before the announcement of new information. Moreover, the average cumulative abnormal 
loss reached the value of $38.51 \%$ on the $15^{\text {th }}$ day following the publication of new information.

\subsection{Results of Nonparametric Statistical Tests}

When testing the response of the Czech stock market to changes of Greek credit rating in the light of the efficient market hypothesis, the values of abnormal stock returns of all companies included in PX index in the event window are compared with zero abnormal returns that are considered a hallmark of the efficient market. In order to accept the null hypothesis, it is necessary that values of abnormal return for the event window on both sides of median should be approximately equal. Table 5 shows values of average abnormal returns of shares included in PX index, which are calculated according to CAPM model. These values are also expressed in absolute values. The ranking of average abnormal returns is indicated in column $R_{i}$.

Table 5 Average abnormal returns of shares traded on PSE in \% during the event window and their ranking

\begin{tabular}{cccc}
\hline & $\overline{A R}_{i \tau}$ & $\left|\overline{A R}_{i \tau}\right|$ & $R_{i}$ \\
\hline AAA & -1.323 & 1.323 & 9 \\
\hline CETV & -1.648 & 1.648 & 11 \\
\hline ČEZ & -0.664 & 0.664 & 1 \\
\hline Erste group & -1.151 & 1.151 & 4 \\
\hline Komerční banka & -1.167 & 1.167 & 5 \\
\hline NWR & -1.354 & 1.354 & 10 \\
\hline ORCO & -1.889 & 1.889 & 12 \\
\hline Pegas Nonvowens & -1.268 & 1.268 & 6 \\
\hline Philip Morris & -1.247 & 1.247 & 2 \\
\hline Telefonica & -0.958 & 0.958 & 3 \\
\hline Unipetrol & -0.979 & 0.979 & 7 \\
\hline VIG & -1.256 & 1.256 & \\
\hline
\end{tabular}

Source: Authors' elaboration

In subsection 2.3, two nonparametric statistical tests were defined. Firstly, average abnormal returns were evaluated using the sign exact test as the scale of our sample is fewer than 25. The sign test is based on the assessment of the direction of measurement deviations from the expected value of the median. When checking the values of abnormal returns based on the CAPM model, none of returns reached a positive value $\left(Z_{+}=0, Z_{-}=12\right)$. Under the null hypothesis, positive and negative values of abnormal returns have binomial distribution $B(0.5,12)$. Table 6 shows cumulative probabilities for binomial distribution $\mathrm{B}(0.5,12)$. 
Table 6 Cumulative probabilities of binomial distribution $B(0.5,12)$

\begin{tabular}{cccccc}
\hline Value of $\boldsymbol{x}$ & $\mathbf{0}$ & $\mathbf{1}$ & $\mathbf{3}$ & $\mathbf{4}$ & $\mathbf{5}$ \\
\hline Probability $\boldsymbol{P}(\boldsymbol{X} \leq \boldsymbol{x})$ & 0.00024 & 0.00317 & 0.01929 & 0.07300 & 0.19385 \\
\hline
\end{tabular}

Source: Hendl (2009)

To confirm the null hypothesis, the following condition must be hold: sum of the sequence of positive abnormal returns $T_{+}$and the sum of the sequence of negative abnormal returns $T_{-}$must be approximately equal. If the efficiency of the Czech stock market is tested using the CAPM model, the null hypothesis of efficiency $\left(\overline{A R}_{i \tau}=0\right)$ can be rejected and the stock market can be considered inefficient at $5 \%$ significance level ( $p$-value $=0.00024<0.05)$.

Secondly, the Wilcoxon signed-rank test was applied. This test is more powerful and is based on absolute values of differences between actual returns and expected values of median. These differences are sorted by their size. The null hypothesis is not rejected if the sum of sequences of positive abnormal returns $T_{+}$and the sum of sequences of negative abnormal returns $T_{-}$are approximately equal. Since abnormal returns achieved negative values only, the value of $T_{+}$is equal to zero while the sum of sequences with negative values $T_{-}$reached the value of 78 . Testing the null hypothesis is performed by comparison of smaller value of $T_{+}$and $T_{\text {- }}$ with precise critical values $W_{12}=13$ at $5 \%$ significance level. The value of $T_{+}=0$ lies within interval of critical values of $W=\langle 0,13\rangle$. Thus, the null hypothesis of efficiency $\left(\overline{A R}_{i \tau}=0\right)$ can be rejected again. Results of both nonparametric tests are summarized in Table 7.

Table 7 Comparison of results of the sing test and Wilcoxon signed-rank test

\begin{tabular}{ccccc}
\hline & \multicolumn{2}{c}{ Sign test } & \multicolumn{2}{c}{ Wilcoxon signed-rank test } \\
\hline & $H_{0}$ & $H_{1}$ & $H_{0}$ & $H_{1}$ \\
\hline CAPM & Rejected & Not rejected & Rejected & Not rejected \\
\hline
\end{tabular}

Source: Authors' elaboration

Based on outcomes of statistical tests provided, it can be concluded that results do not depend on the type of statistical nonparametric test that we apply. When applying the CAPM model for determination of equilibrium yields, the Czech stock market cannot be considered efficient from the statistical point of view. 


\section{Discussion}

In the case of the efficient market, a significant reaction just after the release of negative changes in Greek government bond credit rating would be expected. However, empirical results we achieved indicate that the Czech stock market cannot be considered efficient in terms of semi-strong form of efficiency. Market response to announcement of new information is not clear. The most significant reaction can be seen between the $7^{\text {th }}$ and the $11^{\text {th }}$ days after news announcement. Average aggregated abnormal returns achieved nearly zero value just 14 days after news release. It seems that the Czech stock market anticipated the announcement of negative news regarding changes in Greek credit rating and started to react already earlier (- 15 days). Nevertheless, the adjustment was relatively slow as the Czech market reacted significantly with a delay (+ 7-11 days). Another explanation is that negative values of average abnormal returns were caused by other fundamental factors and news releases about changes in Greek credit rating were not significant in the Czech stock market.

However, our results have shown that prices in the Czech stock market do not respond to new information immediately as it would be expected in a rational marketplace. Our outcomes are in harmony with findings of empirical studies performed only partially before. Tran (2007) rejected the weak form of efficiency in the Czech market using linear and nonlinear methods, which is in concordance with our outcomes. However, Hanousek et al. (2009) found that five-minute returns in Czech, Hungarian and Polish markets reacted strongly to news originating in the EU. Contrary to that, U.S. announcements have a considerable impact on the Czech and Hungarian markets only. The results delivered for the Czech market do reflect the fact that a significant part of traded volume in the Czech market is caused by foreign investors that put more weight on foreign announcements. In addition, Gurgul and Wójtowicz (2014) examined the reaction of the Polish stock market to U.S. announcements based on intraday data. They found that the Polish market reacted to unexpected news from the USA just one minute after a news release. Inconsistency in these results can be caused by different data frequency used, dissimilar data sample, different methods applied when calculating equilibrium returns and different statistical tests used as well.

Nevertheless, our findings could have some important implications especially for regulators and investors. For regulators, our research provides empirical assessment of the current state of information efficiency and detects areas for potential improvements. In bigger markets with more participants, the lower values of abnormal returns were observed on the event day (Nikkinen et al., 2006). It suggests that big markets are generally more efficient than small ones. Attracting potential investors by lowering transaction fees could be an important tool for further development of the Czech stock market. Next, the speed of information dissemination could be supported by highlighting the upcoming news announcements more actively for investors. For investors, fundamental analysis can bring above average returns if share prices do not reflect their inner value. 
Moreover, our results may also have important implications for diversification and risk management strategies as the Czech Republic is preparing to enter the eurozone. We can expect that the Czech market will be more sensitive to macroeconomic shocks, especially those coming from the eurozone. Investors should expect higher volatility when investing in the Czech market.

Our findings also bring some ideas about possible extensions of the topic investigated. The reaction of stock markets can be further examined by separating positive and negative news announcements as done recently for instance by Gurgul and Wójtowicz (2015). The frequency of selected data sample may also play a significant role when investigating the speed and strength of price reactions and the duration of price adjustments after news release as confirmed by Hanousek et al. (2009) and Gurgul and Wójtowicz (2015). In addition, the effects of news announcements could be investigated using different types of companies (according to their size, value or growth). Moreover, examining the downgrades of Greek credit rating, as published by Fitch and S\&P rating agencies, and utilizing more current data sample would lead to results that are more valuable. Finally, the reaction of a stock market could be theoretically related to behavioral aspects of market participants.

\section{Conclusions}

Rational investors seek for mispriced stocks to make a profit on purchase or sale. However, activities of investors on an efficient market lead to the fact that no market participant is able to overcome the respective market and achieve aboveaverage returns. In this paper, we examined the response of the Czech stock market returns to publication of changes of Greek government bonds credit rating as published by Moody's rating agency in the period 2009-2012. For the purpose of this paper, the event study method is applied. All the computations are based on daily log-returns of the shares included in PX index during the whole investigation period. Based on results of the sign test and the Wilcoxon signed-rank test, we can conclude that results of our analysis do not depend on a type of the selected statistical nonparametric test applied. The equilibrium returns, which are important for computation abnormal returns, are calculated with the help of the CAMP model. Based on results of nonparametric statistical tests, the null hypothesis of information efficiency is conclusively rejected. Regarding economic interpretation of statistical outcomes, it can be concluded that the inefficiency of the Czech stock market could be caused by infringement of certain assumptions of the efficient market hypothesis (rational expectations of market participants, a large number of investors, liquidity of market, etc.). Achieved results also have some economic implications for investors and regulators. If equity prices do not reflect their inner value, some investors can make excess returns, given their level of risk exposure. In other words, announcement of news, whether good or bad, may not be reflected in the prices for minutes, hours, days or even longer. Therefore, some investors could purchase an asset at a bargain price before other market participants become aware of the new information release. In addition, the risk premium, transaction 
and information costs must be taken into account as well. Market inefficiency generates important signals also for market regulators. They could focus on fulfilling the assumptions of efficient markets.

\section{Acknowledgments}

This paper was supported by the Czech Science Foundation through project No. 13$13142 S$ and the European Social Fund within the project CZ.1.07/2.3.00/20.0296.

\section{References}

Albuquerque, R. and Vega, C. (2009). Economic News and International Stock Market Co-movement. Review of Finance, 13(3), pp. 401-465. DOI: $10.1093 / \mathrm{rof} / \mathrm{rfn} 020$.

Ashley, J. W. (1962). Stock Prices and Changes in Earnings and Dividends: Some Empirical Results. Journal of Political Economy, 70(1), pp. 82-85.

Beigi, M. H. A. and Budzinski, O. (2013). Reservations on the Use of Event Studies to Evaluate Economic Policy. Intereconomics, 48(3), pp. 174-179. DOI: 10.1007/s10272-013-0459-6.

Březinová, J. (2013). Testování středně silné formy efektivnosti vybraných akciových trhů. (Unpublished master's thesis). VŠB - Technical University of Ostrava.

Boyd, J. H., Hu, J. and Jagannathan, R. (2005). The Stock Market's Reaction to Unemployment News: Why Bad News is Usually Good for Stocks. Journal of Finance, 60(2), pp. 649-672. DOI: 10.1111/j.1540-6261.2005.00742.x.

Büttner, D., Hayo, B. (2012). EMU-Related News and Financial Markets in the Czech Republic, Hungary and Poland. Applied Economics, 44(31), pp. 4037-4053. DOI: 10.1080/00036846.2011.587775.

Büttner, D., Hayo, B., Neuenkirch, M. (2012). The Impact of Foreign Macroeconomic News on Financial Markets in the Czech Republic, Hungary, and Poland. Empirica, 39(1), pp. 19-44. DOI: 10.1007/s10663-010-9153-0.

Campbell, J. Y., Lo, A. W. and MacKinlay, A. C. (1997). The Econometrics of Financial Markets. 2nd ed. New York: Princeton University Press.

Corrado C. J. and Truong C. (2008). Conducting Event Studies with Asia-Pacific Security Market Data. Pacific-Basin Finance Journal, 16(5), pp. 493-521. DOI: 10.1016/j.pacfin.2007.10.005.

Cready, W. M. and Gurun, U. G. (2010). Aggregate Market Reaction to Earnings Announcements. Journal of Accounting Research, 48(2), pp. 289-334. DOI: 10.1111/j.1475-679X.2010.00368.x. 
Dimpfl, T. (2011). The Impact of US News to the German Stock Market - An Event Study Analysis. The Quarterly Review of Economics and Finance, 51(4), pp. 389398. DOI: $10.1016 /$ j.qref.2011.07.005.

Dolley, J. C. (1933). Characteristics and Procedure of Common Stock Split-Ups. Harvard Business Review, 11(1), pp. 316-326.

Égert, B. and Kočenda, E. (2014). The Impact of Macro News and Central Bank Communication on Emerging European Forex Markets. Economic Systems, 38(1), pp. 73-88. DOI: 10.1016/j.ecosys.2013.01.004.

Fama, E. F. (1970). Efficient Capital Markets: A Review of Theory and Empirical Work. Journal of Finance, 25(2), pp. 383-417.

Fama, E. F. (1969). The Adjustment of Stock Prices to New Information. International Economic Review, 10(1), pp. 1-21.

Gurgul, H. and Wójtowicz, T. (2014). The Impact of US Macroeconomic News on the Polish Stock Market. The Importance of Company Size to Information Flow. Central European Journal of Operations Research, 22(4), pp. 795-817. DOI: 10.1007/s10100-014-0343-x.

Gurgul, H. and Wójtowicz, T. (2015). The Response of ATX Intraday Returns to U.S. Macroeconomic News. Czech Journal of Economics and Finance, 65(3), pp. 230253.

Hanousek, J. and Kočenda, E. (2011). Foreign News and Spillovers in Emerging European Stock Markets. Review of International Economics, 19(1), pp. 170-188. DOI: $10.1111 / \mathrm{j} .1467-9396.2010 .00939 . x$.

Hanousek, J., Kočenda, E. and Kutan, A. M. (2009). The Reaction of Asset Prices to Macroeconomic Announcements in New EU Markets: Evidence from Intraday Data. Journal of Financial Stability, 5(2), pp. 199-219.

Harju, K. and Hussain, S. M. (2011). Intraday Seasonalities and Macroeconomic News Announcements. European Financial Management, 17(2), pp. 367-390. DOI: 10.1111/j.1468-036X.2009.00512.x.

Hendl, J. (2009). Přehled statistických metod: Analýza a metaanalýza dat, 3rd ed. Praha: Portál.

Kiete, K. and Uloza, G. (2005). The Information Efficiency of the Stock Markets in Lithuania and Latvia. Working Paper no. 75. Stockholm School of Economics in Riga.

Kim, S. J., Nguyen, D. Q. T. (2009). The Spillover Effects of Target Interest Rate News from the US Fed and the European Central Bank on the Asia-Pacific Stock Markets. Journal of International Financial Markets, Institutions and Money, 19(3), pp. 415-31.

Kohout, P. (1995). Nelineární CAPM. Finance a úvěr, 45(8), pp. 429-442. 
Lintner, J. (1965). The Valuation of Risk Assets and the Selection of Risky Investments in Stock Portfolios and Capital Budgets. Review of Economics and Statistics, 47(1), pp. 13-37.

MacKinlay, A. C. (1997). Event Studies in Economics and Finance. Journal of Economic Literature, 35(3), pp. 13-39.

Mavridis, S. (2018). Greece's Economic and Social Transformation 20082017. Social Sciences. 7(1), pp. 1-14.DOI: 10.3390/socsci7010009.

Nikkinen, J., Omran, M., Sahlström, M. and Äijö, A. (2006). Global Stock Market Reactions to Scheduled U. S. Macroeconomic News Announcements. Global Finance Journal, 17(1), pp.92-104. DOI: 10.1016/j.gfj.2006.06.003.

Sed'a, P. (2012). Impact of the Global Financial Crisis on Stock Market Volatility: Evidence from Central European Stock Market. In: Mathematical Methods in Economics, Karviná: Silesian University in Opava, pp. 787-792.

Sed’a, P. and Jimber del Río, J. A. (2014). Ekonometrická analýza vzájemných vazeb akciových trhů zemí střední Evropy $v$ kontextu finanční krize. In: Řízení a modelování finančních rizik. Sborník příspěvků ze 7. mezinárodní vědecké konference, Ostrava: VŠB-Technical University of Ostrava, pp. 691-699.

Sed'a, P. and Jimber del Río, J. A. (2016). Testing the Weak Form of Efficiency on Chinese Stock Market. In: European Financial Systems 2016. Proceedings of the 13th International Scientific Conference, Brno: Masaryk University, pp. 669-677.

Sharpe, W. F. (1964). Capital Asset Prices - A Theory of Market Equilibrium under Conditions of Risk. Journal of Finance, 19(3), pp. 425-442.

Singh, M., Nejadmalayeri, A. and Lucey, B. (2013). Do U.S. Macroeconomic Surprises Influence Equity Returns? An Exploratory Analysis of Developed Economies. The Quarterly Review of Economics and Finance, 53(2013), pp. 476485. DOI: $10.1016 /$ j.qref.2013.05.002.

Sorokina, N., Booth, D. E. and Thornton, J. H. (2013). Robust Methods in Event Studies: Empirical Evidence and Theoretical Implications. Journal of Data Science, 11 , pp. 575-606.

Švihlíková, I. (2010). Globalizace a krize, 1st Ed. Praha: Grimmus.

Tran, V. Q. (2007). Testing the Weak Form of Efficiency on Czech Stock Market. Politická ekonomie, 6(6), pp. 751-772. DOI: 10.18267/j.polek.622.

Trung, C. (2011). Post-Earnings Announcement Abnormal Return in the Chinese Equity Market. Journal of International Financial Markets, Institutions and Money, 2(5), pp. 637-661. DOI: 10.1016/j.intfin.2011.04.002. 